\title{
Technological Capabilities, Open Innovation, and Eco-Innovation: Dynamic Capabilities to Increase Corporate Performance of SMEs
}

\author{
Luis Enrique Valdez-Juárez ${ }^{1, *(D)}$ and Mauricio Castillo-Vergara ${ }^{2}$ (D) \\ 1 Department of Business and Economics Sciences, Technological Institute of Sonora Mexico, \\ 85000 Obregón, Mexico \\ 2 Faculty of Economy and Business, Universidad Alberto Hurtado, Santiago 6500620, Chile; \\ mhcastillo@uahurtado.cl \\ * Correspondence: levaldez@itson.edu.mx; Tel.: +52-622-103-0253
}

check for updates

Citation: Valdez-Juárez, L.E.; Castillo-Vergara, M. Technological Capabilities, Open Innovation, and Eco-Innovation: Dynamic

Capabilities to Increase Corporate Performance of SMEs. J. Open Innov. Technol. Mark. Complex. 2021, 7, 8. https://doi.org/10.3390/ joitmc7010008

Received: 17 November 2020 Accepted: 28 December 2020 Published: 30 December 2020

Publisher's Note: MDPI stays neutral with regard to jurisdictional clai$\mathrm{ms}$ in published maps and institutional affiliations.

Copyright: $\odot 2020$ by the authors. Licensee MDPI, Basel, Switzerland. This article is an open access article distributed under the terms and conditions of the Creative Commons Attribution (CC BY) license (https:// creativecommons.org/licenses/by/ $4.0 /)$.

\begin{abstract}
Currently, small and medium enterprises (SMEs) play a leading role in most of the world's economies. For this reason, they seek technological competitiveness and improvement of their innovation activities. In this context, open innovation and eco-innovation are important elements to achieve these goals. With this background, the purpose of this paper is to analyze the relationship between technological capability, open innovation, and eco-innovation in corporate performance, testing a structural equation model using SmartPLS in a sample of 684 small and medium-sized companies in Mexico. The main results show that technological capability significantly influences open innovation and eco-innovation practices, not directly in corporate performance, but through open innovation or eco-innovation. Our results also confirm the positive effects that eco-innovation and open innovation have on SMEs' corporate performance. These results have important implications in the literature on dynamic capabilities that have not been previously tested. For companies and decision-makers, it shows why these practices in small and medium-sized companies should be encouraged.
\end{abstract}

Keywords: technological capabilities; open innovation; eco-innovation; SMEs

\section{Introduction}

Since the start of the era based on globalization and the knowledge society, most companies in different regions are struggling to be more innovative and competitive. Technological changes, economic shocks, and market demands have forced many organizations to rethink their business models [1,2]. Therefore, for more than three decades, most companies have been working on research and development $(R \& D)$ of new products with greater intensity to increase their competitiveness level [3,4].

Company managers have focused on approaches and closed processes for the development of innovative activity [5]. Derived from the demands of highly competitive markets, open innovation (OINN) arose as a strategy that breaks with closed innovation paradigms [6]. In the context of Mexican small and medium enterprises (SMEs), open innovation is a novel strategy that allows managers to have access to the external capabilities of an organization to develop their technologies $[7,8]$. New business models based on open innovation allow the integration of technology management and organizational innovation management [3]. This approach makes it possible to eliminate internal limits and involve all organization stakeholders (managers, employees, clients, suppliers, and society), thereby developing innovative behavior and motivation toward a change in culture based on creativity and innovation. Undoubtedly, technological capability (TC) has been a critical element in accelerating innovation activities in companies and is considered one of the most relevant dynamic capacities to achieve sustained competitiveness $[9,10]$. 
The technological capacity involves a series of financial and human resources to achieve efficiency [11]. Technological capacity encompasses the practical and theoretical knowledge that will allow a company to improve and develop new products [12,13]. New technologies have important implications in open innovation processes for SMEs, since with this organizational link, they can meet customer expectations and achieve more excellent corporate financial performance [14].

With the emergence of new production patterns and the growth in the number of customers with socially responsible purchasing behaviors, companies are adopting new business models based on changes that allow them to compete in ecological and/or sustainable market segments $[15,16]$. For this reason, eco-innovation (EINN) is taking on great relevance considering business activities focused on improving products and environmental and economic processes [17]. A significant number of companies have considered introducing eco-innovation to create economic and environmental value [18] simultaneously. This process draws on complex networks of partners and external stakeholders, cooperating through open innovation systems with inbound and outbound practices, to address the challenges posed by eco-innovation [19].

In SMEs' contexts, a significant number are adopting this type of business practice to achieve sustainability [20]. Among the most advanced practices in SMEs are certifications in social responsibility and the adoption of certifications through ISO 14000 and 26000 [21,22]. From a dynamic capabilities theory (DCT) perspective, without a doubt, TC has a direct influence and significant impact on open innovation activities and eco-innovation, which together allow increased business competitiveness and help raise corporate performance (CPERF) [23]. However, SMEs located in emerging regions have internal obstacles (shortterm vision, low-qualified personnel, traditional technologies, and a culture focused on closed innovation processes) [24-26] and external barriers (aggressive competitiveness, globalization of multinational companies, and changes in economic cycles) $[27,28]$.

Despite the growing interest in EINN, few studies have examined its relationship with OINN to affect company performance. Our understanding of the relationship between OINN, EINN, and performance remains fragmented, and it deserves further exploration [29]. More significant efforts are also required to explain the participation of EINN from different points of view [19]. OINN and EINN are in development stages, so additional studies will help to better understand their effects on company performance [30]. A recent systematic study called for the study of EINN in SMEs, explicitly in developing countries, since studies in those countries reach only $22 \%$ versus $75 \%$ in developed countries [31]. Other studies have added that it is not clear if the findings in the literature on open innovation in companies are equally valid in emerging markets, which do not have the same capabilities as companies in developed markets [32].

We consider that SMEs have resource limitations [33,34], particularly in emerging economies where such limitations are usually more critical [35]. Our study makes a significant contribution based on the theory of dynamic capabilities. The proposed model is analyzed from two perspectives: (1) the open innovation model supported by TC for the generation of corporate performance of SMEs and (2) the eco-innovation (sustainable) model with technological support to raise the corporate performance of SMEs. These business models are generally studied and adopted by large and high-tech companies. Therefore, our model makes an important empirical contribution by analyzing these development and competitiveness strategies in SMEs' context in an emerging economy. This research aims to analyze the effects of TC on OINN, EINN, and the corporate performance of SMEs. In addition, the effects of OINN and EINN on corporate performance and the mediation effect they have between TC and the corporate performance of SMEs are analyzed. The research questions are the following: (1) Does TC significantly influence the development of OINN and EINN practices and raise the level of corporate performance in SMEs? (2) What contributes more to CPERF of SMES, the practices of OINN or EINN? (3) Are OINN and EINN business practices that have a mediating role between TC and CPERF in SMEs? The current literature on open innovation and eco-innovation provides an 
important empirical contribution regarding SME businesses in an emerging economy such as Mexico. The first section of the paper introduces the importance of technological capacity, open innovation, and eco-innovation in SMEs' corporate results globally and in Mexico. In the second section, a review of the literature is described, explaining the theoretical foundation through dynamic capabilities and how technological capability contributes to open innovation activities, eco-innovation, and SMEs' corporate performance. Moreover, in this section, the hypotheses of the model are developed and justified. The third section describes the methodology: population, sample, data collection technique, characterization of SMEs, and measurement of the variables under study. In the fourth and fifth sections, the findings are presented, and the results are discussed. The last section of the paper describes the conclusions, limitations, and future lines of research.

\section{Literature Review and Hypothesis Statement}

\subsection{TC, Open Innovation, Eco-Innovation, and Corporate Performance}

From the perspective of dynamic capabilities theory, SMEs are moving toward more innovative and sustainable business models that allow them to increase their competitiveness and satisfy their stakeholders' demands. According to Teece [3], innovative business models are based on technological capacity, open innovation capacity, sustainability, or ecological innovation. Technological capacity is understood as a company's ability to design and develop new processes and products, improve knowledge and human capital skills, and transform knowledge into inputs (products and services) of high added value to increase organizational performance [36,37]. Some studies have explained a strong relationship between development and technological capacity with open innovation activities in SMEs; therefore, it is considered a dynamic capacity that helps competitiveness [38-40]. Currently technological capacity and the use of new disruptive technologies determine the innovation capacity of companies because the collection of information and knowledge from customers, suppliers, and employees is carried out through digital tools that help with direct bi-directional interaction. Thus, open innovation (inbound and outbound) is more effective in developing and creating products [41,42].

At the same time, new technologies are making a strong push in eco-innovation and green supply chains [43]. Studies developed by Kuo and Smith [44] have verified that companies that use technologies in their processes to develop ecological products report a high level of satisfaction of green and/or ecological consumers. Some SMEs are also adopting new technologies (procedures, machines, and equipment) with cleaner and more ecological processes, which has allowed energy savings and cost reduction and the development of products that are friendly to the environment [40,45]. Similarly, the technological and innovative capacities of a company determine the level of financial and corporate performance $[46,47]$. In the same way, SMEs, which have greater technological equipment and make use of digital tools such as social media (Facebook, WhatsApp), online marketing (websites, e-commerce), and artificial intelligence (chatbots) and have a better approach to their markets and consequently raise customer satisfaction, market share, and financial performance [48,49]. However, other studies indicate that sometimes low technological capacity and the incorrect application of TC have little impact on innovation processes, economic growth, and corporate performance [50], while more recent studies report that digitization and the adoption of disruptive technologies are decisive in increasing SMEs ${ }^{\prime}$ competitiveness and financial performance [51]. From the theoretical and empirical point of view, the following hypothetical approaches emerge:

Hypothesis 1 (H1). A Greater technological capacity of SMEs has a significant effect on open innovation activities.

Hypothesis 2 (H2). A Greater technological capacity of SMEs has a significant effect on ecoinnovation activities. 
Hypothesis 3 (H3). A Greater technological capacity of SMEs has a significant effect on corporate performance results.

\subsection{Open Innovation, Eco-Innovation, and Corporate Performance}

The study of open innovation is a relatively new subject in business sciences and innovation management. This type of innovation uses inbound and outbound knowledge to accelerate internal innovation and improve competitiveness. However, given the high complexity and deployment of resources (dynamic capabilities) to achieve maximum efficiency and sustained high financial performance, SMEs have seen little benefit from this type of innovation strategy $[7,8]$. The lack of links with other companies, research centers, and universities has meant that SMEs positively impact the management of open innovation [8]. Like the one developed by Keinz and Marhold [52], some studies show that strategic alliances have helped develop technological capabilities and improve product designs and contribute to improved financial and economic performance. In the same direction, studies indicate that efficient management of internal and external knowledge channeled toward open innovation and involving other interest groups (government, universities, clients, suppliers, and society) causes an increase in SMEs' sales production processes and corporate performance $[53,54]$. The management of innovation has evolved, and today companies are adopting models based on eco-innovation. Some studies on this topic have explained that eco-innovation requires the deployment of resources and environmental strategies and social responsibility to achieve increased customer satisfaction and financial performance $[20,55,56]$.

On the other hand, SMEs face barriers to developing eco-innovation practices; these can be government policies, high costs, demanding markets, and lack of knowledge [6,57]. However, companies that manage to break down these barriers and become sustainable and innovative can obtain many organizational and financial benefits $[57,58]$. From the previous context, the following hypotheses arise:

Hypothesis 4 (H4). A greater focus on SMEs' open innovation activities has a significant effect on corporate performance.

Hypothesis 5 (H5). A greater focus on SMEs' eco-innovation activities has a significant effect on corporate performance.

The hypotheses and flows of the theoretical model are presented in Figure 1.

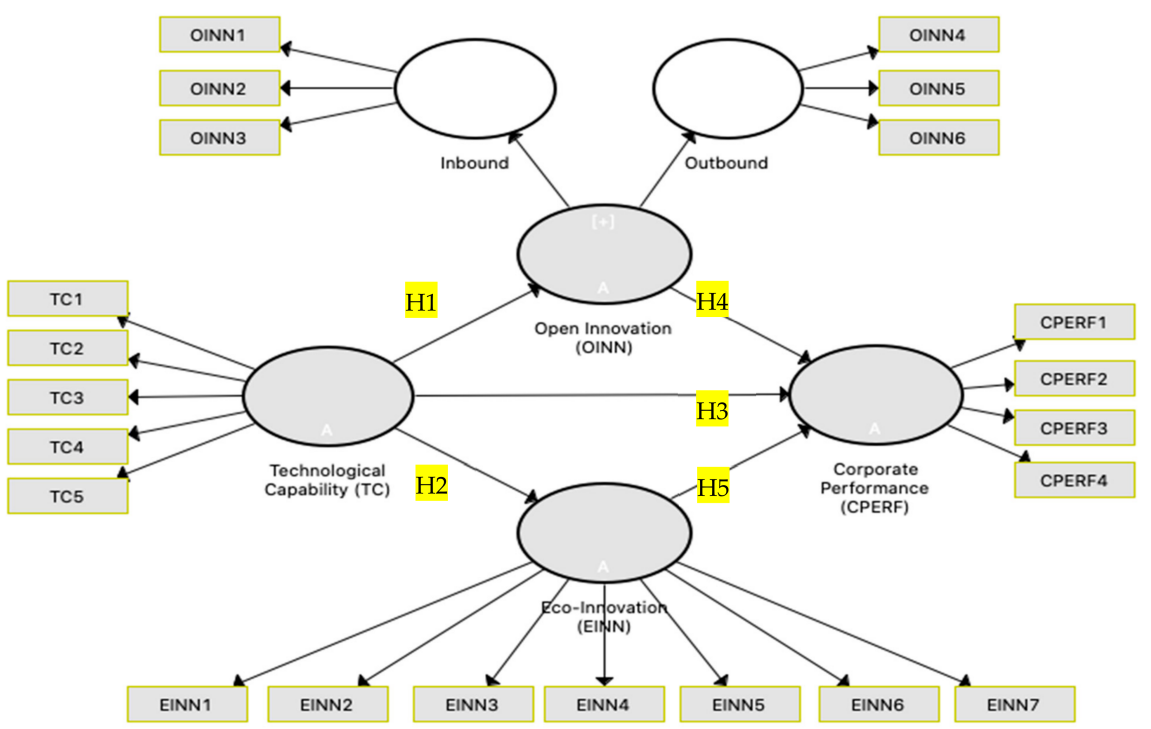

Figure 1. Nomogram of the study. 


\section{Materials and Methods}

\subsection{Sample}

The research design is quantitative and predictive and focused on a population of small companies located in Mexico's northwest region (Sonora, Baja California, and Sinaloa). Among Mexican micro-, small, and medium enterprises (MSMEs), there are more than 6 million businesses, of which $94.5 \%$ are microenterprises and $4.9 \%$ are SMEs; these two groups of companies generate more than $60 \%$ of the jobs in the country, and only $0.02 \%$ correspond to large companies. Businesses in Mexico comprise $49 \%$ of trade companies, $39 \%$ of service companies, and 13\% of manufacturing companies. Data from the Comisión Económica para América Latina y el Caribe CEPAL [59] show that Mexican SMEs are quite heterogeneous, and they require analysis, preferably of a sectoral type. Furthermore, the Global Entrepreneurship Monitor GEM [60] affirms that new public policies of the Mexican government are an attempt to promote research and development (innovation) and sustained economic growth through Sustainable Development Goal (SDG) 8. Mexico is an interesting case that has remained unexplored in the literature. It has had favorable gross domestic product (GDP) growth rates since the 1990s [61], mainly due to large multinational corporations' foreign direct investment activities in the study area. Despite these trends, Mexico's relative performance in terms of innovation has remained below expectations given the size of its economy [62].

The selection of the population followed the principles of the stratified method. SMEs in the commerce sector were selected for this study because they represent crucial Mexican economic participation [63]. The number of employees was taken as a reference; the participating companies have from 10 to 200 employees ( $85 \%$ are small companies with 10 to 50 employees, and 15\% are medium-sized companies with 51 to 200 employees). The information on these companies' total numbers was provided by the National Directory of Economic Units (DENUE) [64]. The sample size was determined so that the maximum margin of error for estimating a proportion (relative frequency of response to a specific item of a question) was less than 0.03 points, with a confidence level of $95 \%$.

A significant limitation in empirical studies is limited resources and low response rates [65]. We addressed this limitation by interviewing the owners or managers of the companies that participated in the research. They had sufficient knowledge and a holistic perspective of organizational processes and practices and the external business environment [66]. The data collection was carried out through a questionnaire in the form of a personal interview with the owner and/or manager of each participating company (see Appendix A). The fieldwork was carried out from March to November 2019. Finally, data on a total of 684 companies were collected. The oldest company has been in operation for 67 years, and the youngest has one year of activity in the sector. Moreover, 15\% of the companies have an environmental certification (ISO14000), and 85\% do not.

\subsection{Characteristics of SMES}

In this section, the main characteristics of the 684 companies that participated in the study are described in detail. For this purpose, it was decided to describe the type of company, the gender of the manager, and the manager's educational level and experience.

Regarding the type of company, in Mexico's specific case, the form of registration and legal constitution of companies through government agencies such as the Ministry of Finance is considered. A legal person refers to a company made up of several partners who contribute to social capital. On the other hand, companies legally registered by a single person are called natural persons with business activity. Table 1 shows the types of companies and the gender of the managers. It is observed that there were many more males than female managers of the two types of companies. 
Table 1. Type of company and gender of the manager.

\begin{tabular}{cccc}
\hline Type of Company & Male & Female & Total \\
\hline Legal person & 174 & 104 & 278 \\
$\%$ & $25.40 \%$ & $15.20 \%$ & $40.60 \%$ \\
Natural person & 233 & 173 & 406 \\
$\%$ & $34.10 \%$ & $25.30 \%$ & $59.40 \%$ \\
Total & 407 & 277 & 684 \\
$\%$ & $59.50 \%$ & $40.50 \%$ & $100.00 \%$ \\
\hline
\end{tabular}

Table 2 shows the type of company, the manager's experience based on years working at the SME, and the manager's level of education. Most of the managers $(77 \%)$ have relative seniority in the company, an average of 1 to 7 years (little experience), and about 23\% have an average of 15 years' seniority (sufficient experience). Those who have enough experience have an average of 20 years' seniority at the SME (1\%). Regarding the level of education, most SME managers $(64 \%)$ have completed university (undergraduate or postgraduate), and another $46 \%$ have completed necessary studies (high school or technical level).

Table 2. Type of company, manager's experience, and level of education.

\begin{tabular}{cccccc}
\hline & $\begin{array}{c}\text { Manager's } \\
\text { Experience }\end{array}$ & & & \multicolumn{3}{c}{$\begin{array}{c}\text { Manager's } \\
\text { Education }\end{array}$} \\
\hline $\begin{array}{c}\text { Type of } \\
\text { Company }\end{array}$ & $\begin{array}{c}\text { Little } \\
\text { Experience }\end{array}$ & $\begin{array}{c}\text { Sufficient } \\
\text { Experience }\end{array}$ & $\begin{array}{c}\text { Wide } \\
\text { Experience }\end{array}$ & Basic & University \\
\hline $\begin{array}{c}\text { Legal person } \\
\%\end{array}$ & 211 & 65 & 2 & 104 & 174 \\
Natural & $30.80 \%$ & $9.50 \%$ & $0.30 \%$ & $15.20 \%$ & $25.40 \%$ \\
person & 319 & 85 & 2 & 214 & 192 \\
$\%$ & $46.60 \%$ & $12.40 \%$ & $0.30 \%$ & $31.30 \%$ & $28.10 \%$ \\
Total & 530 & 150 & 4 & 318 & 366 \\
\hline
\end{tabular}

Table 3 shows the gender, level of education, and experience of the SME managers. The data show that more male than female managers have completed university studies. It is also observed that there are more male than female managers with little experience, but also male managers have sufficient experience.

Table 3. Manager's gender, level of education, and experience.

\begin{tabular}{cccccc}
\hline & $\begin{array}{c}\text { Manager's } \\
\text { Education }\end{array}$ & & & \multicolumn{2}{c}{ Manager's Experience } \\
\hline Gender & Basics & University & $\begin{array}{c}\text { Little } \\
\text { Experience }\end{array}$ & $\begin{array}{c}\text { Sufficient } \\
\text { Experience }\end{array}$ & $\begin{array}{c}\text { Wide } \\
\text { Experience }\end{array}$ \\
\hline Female & 154 & 123 & 231 & 46 & 0 \\
$\%$ & $22.50 \%$ & $18.00 \%$ & $33.80 \%$ & $6.70 \%$ & $0.00 \%$ \\
Male & 164 & 243 & 299 & 104 & 4 \\
$\%$ & $24.00 \%$ & $35.50 \%$ & $43.70 \%$ & $15.20 \%$ & $0.60 \%$ \\
Total & 318 & 366 & 530 & 150 & 4 \\
\hline
\end{tabular}

\subsection{Design and Validation of Data Collection Instrument}

The questionnaire used in the research was directed to managers or directors of SMEs that participated in the study. It was divided into two phases. The first one included the general data of the investigation, such as the sector in which the company operates, its size concerning the number of employees, its geographical location, the gender of the director, the type of company, and the manager's training/or education level. The second section was made up of the study variables: open innovation, eco-innovation, information 
communication technologies, and corporate performance. A pilot test was initially applied with $5 \%$ of the sample to correct any anomalies related to the question design to validate the instrument. To avoid non-response bias, analysis of the single Harman factor was carried out as a tool that helps to diagnose bias through the analysis of common method variance (CMV). We performed confirmatory factor analysis (CFA) using SPSS version 23 software and subsequently examined the reliability of each model construct through the structural equation system (SEM) based on the variance with support from partial least square (PLS). There are two crucial indicators when making these calculations that can lead to the presence of CMV: when performing CFA, the results are grouped into a single factor, and when a single factor explains most of the variance of the model variables $[67,68]$. The results show that the Kaiser-Meyer-Olkin (KMO) value is 0.931 (statistically significant), and the chi-square value is 2781.997. CFA shows that our model is adjusted and grouped into six variables; these factors have a total value of the explained variance of $65.91 \%$, and the first factor has a value of $26.55 \%$, which shows that non-response bias is unlikely to exist in the proposed research model.

\subsection{Measurement of Variables}

The variables used in the research were measured through first-order reflective onedimensional variables and second-order multidimensional constructs in mode A. The technique used to analyze the proposed model was a two-step approach. (1) The model was drawn with the first-order dimensions and their respective indicators. These dimensions were then connected to the main construct, and the corresponding analysis was made to obtain the latent variables scores. (2) The score values were used to analyze the first-order dimensions, and they were connected with the second-order construct for later execution in SmartPLS version 3.3.2 [69]. The SEM-PLS method was chosen for this research due to the following factors: (1) the nature of the items of a reflective type, (2) adaptation to the design of the quantitative-predictive type of research, and (3) the size of the sample and the robustness of the model with first- and second-order constructs [70,71]. All variables were measured using a 5 -point Likert scale $(1=$ completely disagree to $5=$ completely agree). The justification for the selection was that this scale allowsd us to relate variables and estimate effects with models of structural equations [72], specifically in PLS-SEM models [73].

\subsubsection{Technological Capability (TC)}

This reflective construct was measured in a unidimensional way considering the adoption and use of technology to improve a company's innovation. To measure it, five questions were structured, adapted from $[10,74,75]$. The construct meets the minimum requirements of reliability and validity: the factor load ranges from 0.721 to 0.857 , Cronbach's alpha is 0.863 , and composite reliability has a value of 0.902 ; moreover, the mean-variance extracted is 0.648 .

\subsubsection{Open Innovation (OINN)}

This reflective construct was measured in a multidimensional way, considering incoming and outgoing innovation, as a means of increasing corporate performance. The construct was made up of two dimensions: (1) inbound, which includes three questions, and (2) outbound, made up of 3 questions. The questions of this dimension were adapted from Ref. [6,7]. The construct meets the minimum requirements for reliability and validity: the factor load ranges from 0.727 to 0.811 , Cronbach's alpha 0.879 , and composite reliability has a value of 0.908 ; moreover, the mean-variance extracted is 0.623 .

\subsubsection{Eco-Innovation (EINN)}

This reflective construct was measured in a unidimensional way, considering ecological and sustainable practices in innovation and their relationship with corporate performance. The seven questions of this dimension were adapted from Ref. [76,77]. The 
construct meets the minimum requirements of reliability and validity: the factor load ranges from 0.765 to 0.856 , Cronbach's alpha 0.925 , and composite reliability has a value of 0.939; moreover, the mean-variance extracted is 0.690 .

\subsubsection{Corporate Performance (CPERF)}

This construct was measured in a unidimensional way considering the opinions of the directors and/or managers of the SMEs on their financial and economic benefits in the last 2 years derived from the implementation of innovative actions. To measure it, four questions were structured, adapted from Ref. [16,78,79]. The construct meets the minimum requirements of reliability and validity: the factor load ranges from 0.718 to 0.793 , Cronbach's alpha 0.750 , and composite reliability has a value of 0.939 ; in addition, the mean-variance extracted is 0.690 .

\section{Results}

\subsection{Measurement Model}

In addition to the individual reliability of the items, presented in the previous section, which was shown to be very close to or above 0.707 [80,81], this section shows the internal consistency of the model through the reliability of the constructs, Cronbach's

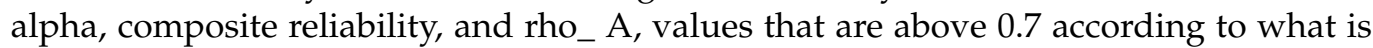
recommended $[70,81]$ (see Table 4 ).

Table 4. Reliability and validity by construct. TC, technological capability. OINN, open innovation; EINN, eco-innovation; CPERF, corporate performance.

\begin{tabular}{cccc}
\hline Construct & Cronbach's Alpha & rho_A & $\begin{array}{c}\text { Composite } \\
\text { Reliability }\end{array}$ \\
\hline TC & 0.863 & 0.864 & 0.902 \\
OINN & 0.879 & 0.880 & 0.908 \\
Outbound & 0.832 & 0.832 & 0.899 \\
Inbound & 0.797 & 0.800 & 0.881 \\
EINN & 0.925 & 0.925 & 0.939 \\
CPERF & 0.750 & 0.753 & 0.842 \\
\hline
\end{tabular}

Convergent and discriminant validity are shown in the following tables. The data indicate that the average variance extracted (AVE) explains at least $50 \%$ of the variance of the indicators analyzed in the model. In the same way, discriminant validity indicates that the square root of AVE (values on the diagonal) is greater than the values of the correlations of the constructs $[82,83]$ (see Table 5).

Table 5. Discriminant validity. AVE, average variance extracted.

\begin{tabular}{cccccc}
\hline Construct & AVE & TC & OINN & EINN & CPERF \\
\hline CTs & 0.648 & 0.805 & & & \\
OINN & 0.623 & 0.523 & 0.790 & & \\
EINN & 0.690 & 0.456 & 0.344 & 0.830 & \\
CPERF & 0.571 & 0.174 & 0.336 & 0.204 & 0.756 \\
\hline
\end{tabular}

\subsection{Structural Model}

First, the evaluation of the algebraic sign $(+,-)$, the magnitude (value of the coefficient and of $t$ ), and the statistical significance of the path coefficients are shown; this analysis was carried out using the bootstrapping technique with 5000 samples. In addition, standard deviation and explained variance $\left(R^{2}\right)$ are shown by multiplying the value of the path coefficient and the correlation. This analysis was performed under a one-tailed Student's $t$ distribution with $n-1$ degrees of freedom (Table 6). 
Table 6. Hypothesis test results.

\begin{tabular}{cccccccc}
\hline Hypothesis & Path Coefficient & SD & T Value & $p$-Value & $\mathbf{f}^{2}$ & $\begin{array}{c}\text { Variance } \\
\text { Explained: } \mathbf{R}^{\mathbf{2}}\end{array}$ & Result \\
\hline H1: TC $\rightarrow$ OINN & $0.523^{* * *}$ & 0.032 & 16.337 & 0.000 & 0.377 & $27.4 \%$ & Supported \\
H2: TC $\rightarrow$ EINN & $0.456^{* * *}$ & 0.035 & 12.880 & 0.000 & 0.262 & $20.8 \%$ & Supported \\
H3: TC $\rightarrow$ CPERF & 0.025 & 0.046 & 0.532 & 0.302 & 0.005 & $0.4 \%$ & Unsupported \\
H4: OINN $\rightarrow$ CPERF & $0.166^{* * *}$ & 0.043 & 3.848 & 0.000 & 0.025 & $3.8 \%$ & Supported \\
H5: EINN $\rightarrow$ CPERF & $0.136^{* * *}$ & 0.044 & 3.080 & 0.001 & 0.016 & $2.8 \%$ & Supported \\
\hline
\end{tabular}

Tables 6 and 7 show the hypothesis test results; only $\mathrm{H} 3$ does not have empirical support. On the other hand, $\mathrm{H} 1, \mathrm{H} 2, \mathrm{H} 4$, and $\mathrm{H} 5$ show a strong positive and significant relationship at $99 \%$. In addition to the beta value, algebraic sign, and significance, we show the value of $t$, which is greater than 2 . This test corroborates the results of the relationships that have empirical support in our model. In addition, the bootstrapping test with 5000 samples includes the confidence intervals of percentiles (CI) and corrected biases (CI); in the confidence intervals, zero is not presented, thereby demonstrating the strength and magnitude of the relationships of model constructs.

Table 7. Percentile confidence interval (CI) and bias-corrected.

\begin{tabular}{cccccc}
\hline \multirow{2}{*}{ Hypothesis } & Path Coefficients & Percentile & Percentile & Bias Corrected & Bias Corrected \\
\cline { 3 - 4 } & & CI 5\% & CI 95\% & & 5\% \\
\hline H1: TC $\rightarrow$ OINN & $0.523^{* * *}$ & 0.467 & 0.574 & 0.467 & 0.574 \\
H2: TC $\rightarrow$ EINN & $0.456^{* * *}$ & 0.397 & 0.513 & 0.396 & 0.511 \\
H3: TC $\rightarrow$ CPERF & 0.025 & -0.051 & 0.103 & -0.051 & 0.101 \\
H4: OINN $\rightarrow$ CPERF & $0.166^{* * *}$ & 0.095 & 0.240 & 0.093 & 0.235 \\
H5: EINN $\rightarrow$ CPERF & $0.136^{* * *}$ & 0.065 & 0.208 & 0.064 & 0.209 \\
\hline
\end{tabular}

*** $p<0.001 ; n=5000$ subsamples; $\mathrm{t}(0.05 ; 4999)=1645 ; \mathrm{t}(0.01 ; 4999)=2327 ; \mathrm{t}(0.001 ; 4999)=3092$.

\subsubsection{Indicators of Predictive Analysis of the Model}

To evaluate the model's predictive power, the values of the coefficient of determination (adjusted $\mathrm{R}^{2}$ ) of the endogenous constructs were analyzed. The results of our model indicate the following: $\mathrm{OINN}=0.273, \mathrm{EINN}=0.206$, and CPERF $=0.066$. According to Chin [83], the values for open innovation and eco-innovation are moderate; however, the value is a bit weak for corporate performance. Falk and Miller [84] suggested that a value of 0.10 meets the requirements to achieve a minimum predictive power level (see Figure 2). We analyzed the effect size with the value of $\mathrm{f}^{2}$; this analysis shows the effect and/or value that the construct contributes, exogenous to endogenous. The results of the key relationships with the greatest strength are as follows: TC-OINN $=0.377$ (big effect), TC-EINN $=0.262$ (moderate effect), OINN-CPERF $=0.025$ (small effect), and EINN-CPERF $=0.016$ (small effect). These values are taken according to the recommendation of Ref. [83,85].

\subsubsection{Measuring the Predictive Relevance of the Model}

To evaluate the model's predicative relevance, the Stone-Geisser test was carried out using the blindfolding technique to determine the value of $\mathrm{Q}^{2}$. Values of the reflective variables greater than zero are considered to have adequate predictive relevance [83]. Our model results show the following values: OINN $=0.169, \mathrm{EINN}=0.141$, and CPERF $=0.037$. In addition, another measure of goodness of fit was incorporated to measure the global model; for this, the standardized root mean residual sack (SRMR) was considered, a value that must be below $1[70,86]$. Our value is 0.081 , which shows that the proposed model has a good fit. 


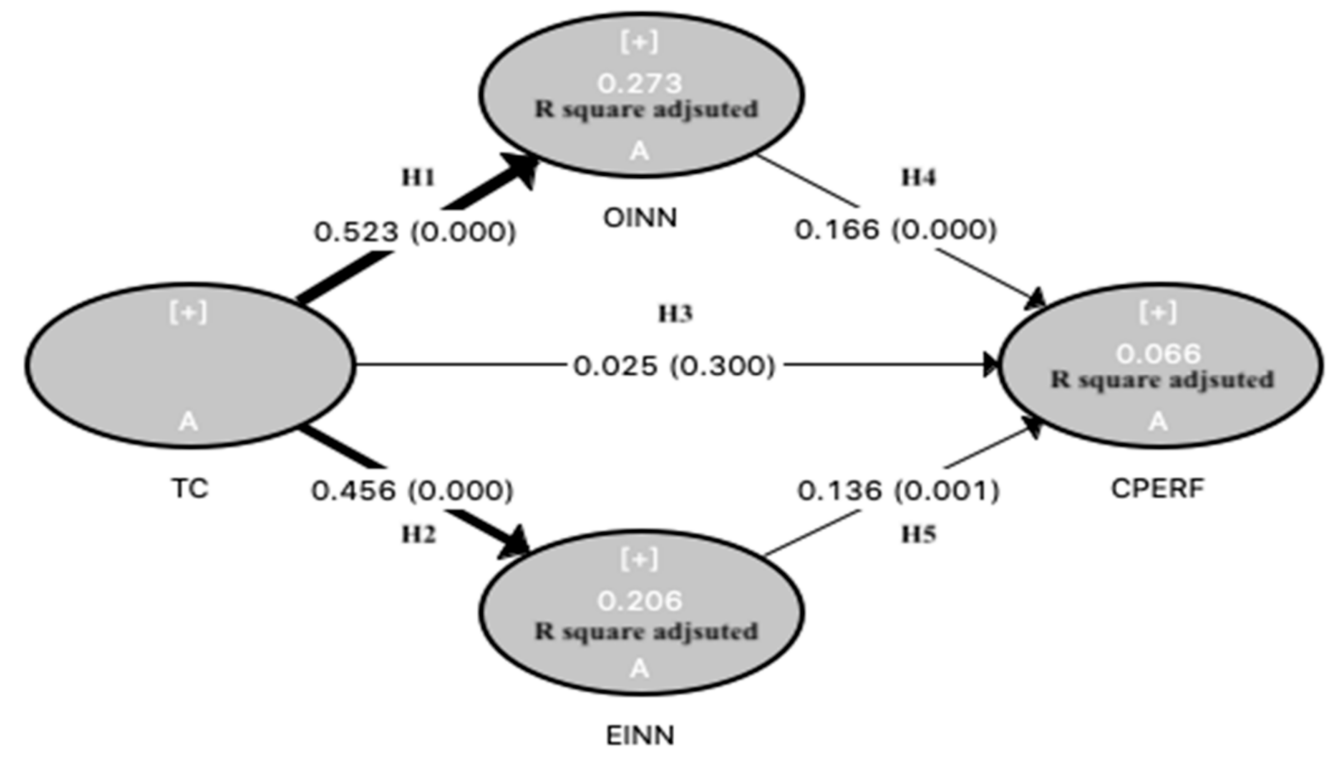

Figure 2. Nomogram of the study (structural model).

\subsubsection{Multiple Mediation Analysis}

The single-step multiple mediator model was used to test the mediation effect $\left(c=c^{\prime}\right.$ $\left.+a_{1} \times b_{1}+a_{2} \times b_{2}\right)$. This implies first estimating the importance of the direct effect $\left(c^{\prime}\right)$. Subsequently, two steps are carried out: (1) determining the indirect effects $\left(a_{1} \times b_{1}\right)$ and $\left(a_{2} \times b_{2}\right)$ using the bootstrapping technique with 5000 samples, with calculations of $90 \%$ confidence intervals [87,88]; and (2) determining the type of effect and magnitude of the indirect effects in relation to the total effect, in order to determine the importance of the direct and indirect effects and the type of mediation between variables [88,89]. It is also important to measure the value of the variance accounted for (VAF) indicator [90]. Hair et al. (2017) and Carrión et al. (2017) [90,91] indicated total or complete mediation when $\mathrm{a} \times \mathrm{b}$ is significant and the value of $\mathrm{c}^{\prime}$ is not significant, which we found in the analysis of our results. Furthermore, the VAF value is $86 \%$ above the average value, which shows that OINN and EINN have a mediating effect between TC and corporate performance: $\mathrm{H} 1=\mathrm{TC} \rightarrow \mathrm{CPER}=\mathrm{c}^{\prime} ; \mathrm{H} 2=\mathrm{TC} \rightarrow \mathrm{OINN} \rightarrow \mathrm{CPERF}=\mathrm{a}_{1} \times \mathrm{b}_{1} ;$ and $\mathrm{H} 3=\mathrm{TC} \rightarrow \mathrm{EINN} \rightarrow$ $\mathrm{CPERF}=\mathrm{a}_{2} \times \mathrm{b}_{2}$.

Table 8 and Figure 3 show the results obtained from multiple mediation analysis. The results show that open innovation and eco-innovation are measurement variables that help increase the relationship between TC and SMEs' corporate performance.

Table 8. Multiple mediation. VAF, variance accounted for.

\begin{tabular}{ccccccc}
\hline \multicolumn{5}{c}{ Bootstrap 90\% } \\
& $\begin{array}{c}\text { Path } \\
\text { Coefficient }\end{array}$ & $\begin{array}{c}\text { Percentile } \\
\text { CI }\end{array}$ & & $\begin{array}{c}\text { Bias } \\
\text { Corrected CI }\end{array}$ & & VAF \\
\hline $\mathrm{H}_{1} \mathrm{c}^{\prime}$ & $0.025^{\mathrm{nsig}}$ & -0.051 & 0.102 & -0.051 & -0.051 & \\
$\mathrm{a}_{1}$ & $0.523^{\mathrm{sig}}$ & 0.470 & 0.572 & 0.471 & 0.472 & \\
$\mathrm{a}_{2}$ & $0.456^{\mathrm{sig}}$ & 0.396 & 0.397 & 0.397 & 0.398 & \\
$\mathrm{~b}_{1}$ & $0.166^{\mathrm{sig}}$ & 0.094 & 0.239 & 0.093 & 0.092 & \\
$\mathrm{~b}_{2}$ & $0.136^{\mathrm{sig}}$ & 0.063 & 0.207 & 0.063 & 0.063 & \\
& Point estimate & Percentile & & Bias corrected & & \\
$\mathrm{H}_{2}$ & $0.087^{\mathrm{sig}}$ & 0.044 & 0.137 & 0.044 & 0.043 & 0.50 \\
$\mathrm{H}_{3}$ & $0.062^{\mathrm{sig}}$ & 0.025 & 0.106 & 0.025 & 0.025 & 0.36 \\
Total indirect effect & 0.149 & 0.069 & 0.243 & 0.069 & 0.068 & 0.86 \\
Total effect & 0.174 & & & & & \\
VAF & $86 \%$ & & & & & \\
\hline
\end{tabular}




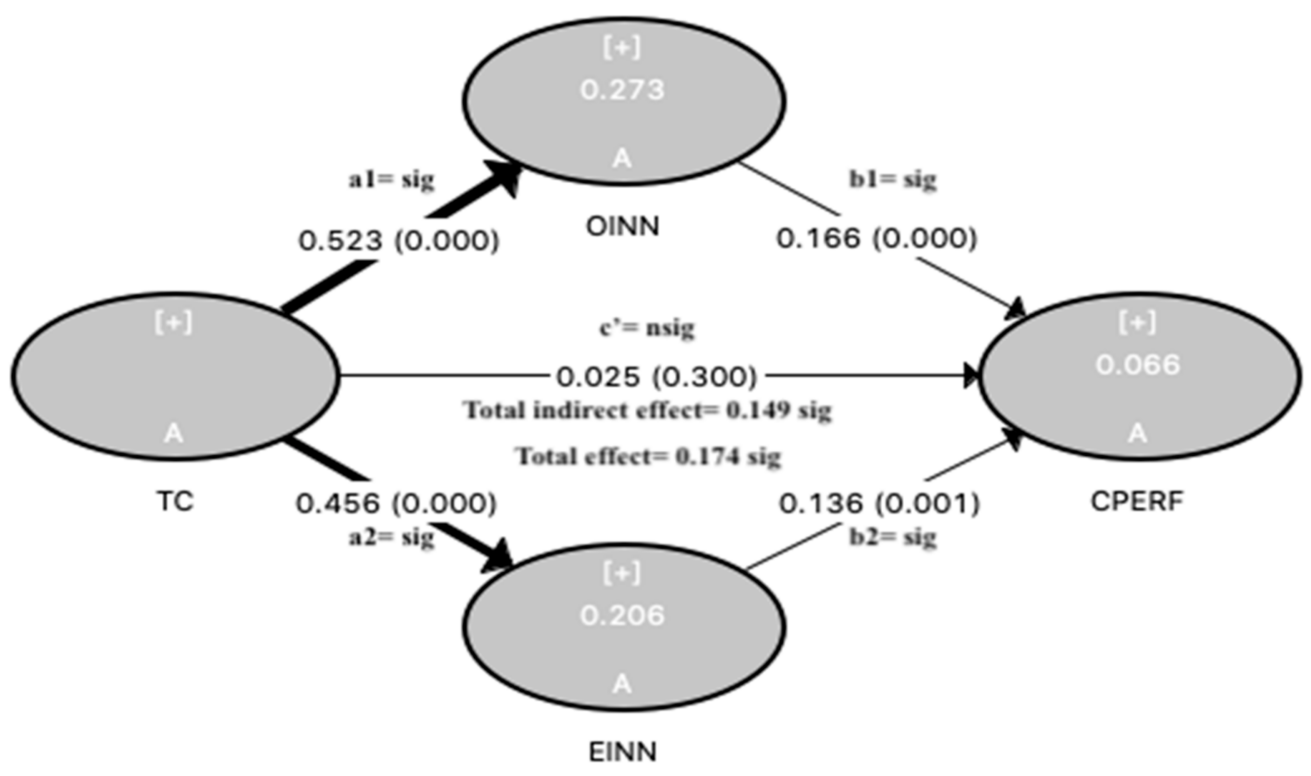

Figure 3. Nomogram of the study (multiple mediation).

\subsubsection{Multi-Group Analysis}

In the study, a non-parametric PLS-MGA analysis was used; this test requires confirmation of the measurement invariance between two groups $(1=$ certified $(14 \%$ of the total sample) and $2=$ not certified ( $86 \%$ of the total sample) in ISO 14000). For this, the configurational invariance was analyzed, and the compositional invariance was presented [80]. Regarding the configurational invariance, it was confirmed that the treatment of data for the measurement of the two models and the structural and algorithm configuration were the same for both groups (see Table 9). For compositional invariance, a permutation method was used with a sample of a minimum of 1000 permutations with a significance level of $5 \%$. This method compared the original score correlations with the empirical distribution correlations after the permutation process. If the correlations exceed $5 \%$, it is established that there is compositional invariance.

Table 9. Configurational invariance.

\begin{tabular}{ccccc}
\hline Constructs & Correlation & $\mathbf{5 . 0 \%}$ & $\begin{array}{c}p \text {-Value } \\
\text { (Permutation) }\end{array}$ & Result \\
\hline Corporate performance (CPERF) & 0.976 & 0.906 & 0.263 & Yes \\
Eco-Innovation (EINN) & 0.996 & 0.997 & 0.033 & No \\
Technological capability (TC) & 0.996 & 0.997 & 0.024 & No \\
Open innovation (OINN) & 1.000 & 1.000 & 0.105 & Yes \\
\hline
\end{tabular}

This analysis is carried out in the following section with the analysis of differences in the beta coefficients. The results show that SMEs that do not have certifications in environmental aspects are carrying out technological, innovative, and eco-innovative practices to achieve higher financial returns (see Table 10). 
Table 10. Hypothesis (Multigroup Analysis).

\begin{tabular}{cccccccc}
\hline Hypothesis & Path (G1) & Path (G2) & t Value (G1) & t Value (G2) & $\boldsymbol{p}$-Value (G1) & $\boldsymbol{p}$-Value (G2) & Result \\
\hline H1: TC $\rightarrow$ OINN & 0.506 & 0.521 & 5.260 & 15.214 & 0.000 & 0.000 & G1 $<$ G2 \\
H2: TC $\rightarrow$ EINN & 0.388 & 0.460 & 4.952 & 12.149 & 0.000 & 0.000 & G1 $<$ G2 \\
H3: TC $\rightarrow$ CPERF & 0.024 & 0.019 & 0.109 & 0.392 & 0.457 & 0.347 & G1 $>$ G2 \\
H4: OINN $\rightarrow$ CPERF & 0.148 & 0.172 & 1.034 & 3.569 & 0.151 & 0.000 & G1 < G2 \\
H5: EINN $\rightarrow$ CPERF & 0.030 & 0.149 & 0.211 & 3.085 & 0.416 & 0.001 & G1 $<$ G2 \\
\hline
\end{tabular}

ISO 1400 was selected to develop the multi-group analysis, mainly due to the organizational benefits it brings to companies. According to the ISO [92], this certification is based on a management system that improves product quality, operational efficiency, environmental performance, and health and safety in the workplace. It can also be a crucial factor in defining stable executive leadership and setting goals for SMEs' business employees. On the other hand, the high cost of implementing this type of certification prevents SMEs from adopting it in a timely and permanent manner. Therefore, the company's size and age are decisive factors in this business strategy [93]. On the other hand, it has been observed that companies in the industrial sector, such as manufacturing (automotive, nanotechnology, and aerospace), adopt this type of environmental management certification to a greater extent $[57,94]$. Additionally, it was decided to analyze this business practice because most companies have not adopted this certification, so it is interesting to measure it and verify its effects on corporate performance, eco-innovation, and open innovation.

In addition, Table 11 shows that SMEs that do not adopt ISO 1400 certification achieve fewer significant results in corporate performance, but these results are slightly above those of SMEs that do have certification in this environmental standard.The same behavior is manifested for eco-innovation and open innovation. These results may be because for Latin American SMEs, specifically Mexican ones, this type of norm is not mandatory, and these environmental management practices are in an initial phase of adoption [22,95]. Therefore, these certification standards represent a challenge for SMEs and an important area of opportunity to increase their competitiveness and performance.

Table 11. Adjusted $\mathrm{R}^{2}$ (multigroup).

\begin{tabular}{cccccc}
\hline Construct & $\mathbf{R}^{\mathbf{2}} \mathbf{( G 1 )}$ & $\mathbf{R}^{\mathbf{2}} \mathbf{( G 2 )}$ & $\mathbf{5 . 0 0 \%}$ & $\mathbf{9 5 . 0 0 \%}$ & $\boldsymbol{p}$-Value (Permutation) \\
\hline Corporate & -0.001 & 0.071 & -0.071 & 0.137 & 0.046 \\
performance & 0.142 & 0.210 & -0.145 & 0.175 & 0.229 \\
Eco-innovation & 0.248 & 0.271 & -0.156 & 0.172 & 0.414 \\
Open innovation & 0
\end{tabular}

\section{Discussion}

Based on the theory of dynamic capabilities and the call to develop new innovative and sustainable business models, we tested a theoretical model that includes dynamic capabilities, open innovation, and eco-innovation with 684 SMEs located in a developing economic region. Next, we present the main elements derived from the investigation, both conceptual and practical.

First, we analyze the effects that TC has had on open innovation practices, ecoinnovation, and corporate performance results. The results show that SMEs' technological capability has a more significant impact on open innovation activities since it helps them collect information, transfer it within the company, and improve processes and products. These findings are in line with empirical studies showing that SMEs with greater technological capacity and on the path of digitizing their processes are more likely to adopt open innovation and be more competitive $[38,41]$. On the other hand, TC has a similar impact on the eco-innovation activities carried out by SMEs. With the new environmental and ecological regulations established by global organizations, these types of companies are adopting these new business models to comply with regulations and meet the needs 
of green and/or ecological markets. A determining factor of adopting eco-innovation is the impulse to use technology [96] because developing cleaner innovations is more complex and requires more outstanding technological capability [97]. These results are in line with the empirical studies analyzed in the paper because disruptive technologies and digitization help SMEs improve their production processes, save energy, and improve product designs with less polluting materials $[44,45]$.

However, in our model, technological capability does not have a significant impact on corporate performance results. Some explanations for this are related to the companies analyzed. The commercial SMEs under study have low technology since their focus is not on developing new products. Moreover, for this reason, they have a lower capacity to absorb external and internal technology, and they fail to benefit from the supply of technology [96]. These findings are consistent with the argument that an organization's capacities work to build and integrate competencies in all strategies, but ultimately in performance [30]. Therefore, companies in this sector require public policies to incorporate technological capabilities to be efficient $[50,75]$.

Next, we analyze the findings related to the impact of open innovation and ecoinnovation on corporate performance. The results indicate that the open innovation activities carried out by SMEs have a moderate but significant effect on corporate performance results. These findings are in line with the theoretical and empirical context $[6,98]$.

Companies in the commerce sector can create value for their consumers using open innovation [99]. However, to carry it out, factors such as creativity, the ability to learn, and tolerance for failure must be developed to motivate the actors to participate $[100,101]$. Issues that are not well developed in Mexican SMEs require greater technological capacity, incoming innovation (exchange of knowledge with other sectors and companies), and outgoing innovation (design of new products, patents, and inventions) to improve organizational and economic results [53,54].

With a similar impact and a significant effect, we find that eco-innovation plays an essential role in the corporate performance results of SMEs; however, these new practices for these types of companies are novel and require greater maturity, commitment, and sustainable organizational business practices to achieve better results $[3,55,57]$.

\section{Conclusions}

This study has important theoretical and empirical implications. From the theoretical perspective, the study makes an essential contribution to developing and analyzing the theory of dynamic capabilities through a theoretical model, which includes open innovation and eco-innovation supported by technological capability. This model was tested with SMEs in Mexico, an economy classified as emerging or developing. Mexico is a fascinating case because, despite good macroeconomic indicators, its relative performance in terms of innovation has remained below expectations given the size of its economy [62]. Moreover, it is established that it is unclear whether the assumptions and findings of the dynamic capabilities literature in developed markets, where most of the studies have been concentrated, are equally valid for companies in emerging markets [32].

From an empirical perspective, the study has important implications for managers and business owners. It shows that SMEs that have efficient technological capacity and adopt innovative and sustainable business models can become more competitive and profitable for more extended periods. This can allow them to achieve a greater competitive advantage, be more innovative, and improve their corporate performance results by taking the following steps: (1) intensifying open innovation activities (interacting more frequently with interest groups); (2) adopting disruptive technology and free software to improve processes; (3) establishing relationships with research centers and universities for the development of technological, innovative, and ecological projects; (4) seeking support from the national government or foreign entities for the development of technological and innovative projects; (5) adopting ongoing training programs for members of the organization; (6) adopting certifications focused on ecological and/or green practices for 
product development. Regarding the implications of public policies, the results show that SMEs that develop open innovation and eco-innovation improve their performance, bringing better financial results. Therefore, public policies should encourage the adoption of these practices. Previous results indicate that companies' decisions on eco-innovation are stimulated by national regulations [18]. Another factor that justifies public support for innovation is market failure, such as difficulties that companies of this size have in financing R\&D activities [102]. Finally, provisions that promote the transfer and exchange of knowledge between academia and industry could incorporate regulations and policies that stimulate eco-innovation, even as a requirement for financing [96].

The research is not free of limitations, and it is important to try to minimize them in future studies. One of the main limitations in this type of study is the source of the data because the information collected comes from the managers of the surveyed companies' subjective opinions, which can sometimes lead to bias. Future studies could consider the participation of workers or consumers. Another limitation is the development of measurement scales since they were adapted from studies in different contexts. The statistical analysis used variance; future research might consider statistical analysis that focuses on covariance. Due to the importance of continuously analyzing SMEs in most countries, it is recommended to continue with studies that reveal the practices these companies develop. It would be interesting to contrast whether the model behaves the same in less-knowledge-intensive service companies (LKIS) versus knowledge-intensive service companies (KIS). Other aspects that require attention to strengthen the theoretical models are phenomena related to intellectual capital, intellectual property, and business sustainability, especially in emerging economies.

Author Contributions: L.E.V.-J. is the author of this manuscript and all of its contents and was responsible for designing the instrument and collecting and analyzing data in this investigation. M.C.-V. collaborated on this manuscript in improving the abstract section, the introduction, the literature review, and the conclusions. All authors have read and agreed to the published version of the manuscript.

Funding: This paper received funding for development and publication by the Program for Strengthening Educational Quality (PFCE, 2020) of the Secretariat of Public Education of Mexico, and PROFAPI (2020_0010), ITSON Research Institutional Strengthening Program.

Institutional Review Board Statement: The study was conducted according to the guidelines of the Declaration of Helsinki, and approved by the Institutional Review Board (or Ethics Committee) of Instituto Tecnológico de Sonora (PROFAPI 2020_0010).

Informed Consent Statement: Informed consent was obtained from all subjects involved in the study.

Data Availability Statement: The data and the questionnaire used in the study are available to other authors who require access to this material.

Conflicts of Interest: The author declares no potential conflicts of interest with respect to the research, authorship, and publication of this article.

\section{Appendix A. (Survey)}

Dear company and/or manager: We ask you to please help us answer the following questions of this research project. Thank you very much for your collaboration. Instructions: Please mark with an X, in blocks I and II, the option that you consider most appropriate and closest to the reality of your organization.

\section{Block I}

1. Activity sector: $\square$ Trade

2. Gender: $\square$ Female $\square$ Male

3. Size of the company: $\square$ Small (10-50 employees) $\square$ Medium (51-200 employees)

4. Level of education: $\square$ Basic studies $\square$ University studies

5. Type of company: $\square$ Moral $\square$ Physical

6. Geographic location of the company: $\square$ Sonora $\square$ Baja California $\square$ Sinaloa 
Block II

\begin{tabular}{|c|c|c|c|c|c|c|}
\hline \multirow[b]{2}{*}{ Technological capability (TC): In the last 2 years your company: } & \multicolumn{5}{|c|}{$\begin{array}{l}\text { 1: Completely Disagree, } \\
\text { 5: Completely Agree }\end{array}$} & \multirow{2}{*}{$\begin{array}{c}\text { Authors (Researchers)/ } \\
\text { Factor Load }\end{array}$} \\
\hline & 1 & 2 & 3 & 4 & 5 & \\
\hline TC1: Had information technology better than the competition & $\square$ & $\square$ & $\square$ & $\square$ & $\square$ & 0.776 \\
\hline TC2: Used technological tools to negotiate with suppliers & $\square$ & $\square$ & $\square$ & $\square$ & $\square$ & 0.721 \\
\hline TC3: Used software for intradepartmental communication & $\square$ & $\square$ & $\square$ & $\square$ & $\square$ & 0.831 \\
\hline TC4: Had qualified personnel to handle ICT & $\square$ & $\square$ & $\square$ & $\square$ & $\square$ & 0.857 \\
\hline TC5: Used ICT for decision-making & $\square$ & $\square$ & $\square$ & $\square$ & $\square$ & 0.832 \\
\hline Open innovation: In the last 2 years your company: & 1 & 2 & 3 & 4 & 5 & {$[6,7,103,104]$} \\
\hline \multicolumn{7}{|l|}{ Inbound } \\
\hline OINN1: Participated in projects with other companies in the sector & $\square$ & $\square$ & $\square$ & $\square$ & $\square$ & 0.853 \\
\hline OINN2: Had direct participation of customers in improving products & $\square$ & $\square$ & $\square$ & $\square$ & $\square$ & 0.819 \\
\hline $\begin{array}{l}\text { OINN3: Had participation of suppliers in improving innovation } \\
\text { processes }\end{array}$ & $\square$ & $\square$ & $\square$ & $\square$ & $\square$ & 0.858 \\
\hline \multicolumn{7}{|l|}{ Outbound } \\
\hline OINN4: Had sales of licenses or registration of new brands & $\square$ & $\square$ & $\square$ & $\square$ & $\square$ & 0.842 \\
\hline OINN5: Had sales of intangible assets such as know-how & $\square$ & $\square$ & $\square$ & $\square$ & $\square$ & 0.880 \\
\hline OINN6: Developed new businesses with internal knowledge & $\square$ & $\square$ & $\square$ & $\square$ & $\square$ & 0.873 \\
\hline Eco-innovation: In the last 2 years your company has: & 1 & 2 & 3 & 4 & 5 & {$[76,77,105-108]$} \\
\hline EINN1: Designed products that reduce the use of materials & $\square$ & $\square$ & $\square$ & $\square$ & $\square$ & 0.856 \\
\hline EINN2: Designed products with components for reuse or recycling & $\square$ & $\square$ & $\square$ & $\square$ & $\square$ & 0.835 \\
\hline $\begin{array}{l}\text { EINN3: Designed products to avoid or reduce the use of hazardous } \\
\text { materials }\end{array}$ & $\square$ & $\square$ & $\square$ & $\square$ & $\square$ & 0.765 \\
\hline INN4: Used production processes that minimize or reduce waste & $\square$ & $\square$ & $\square$ & $\square$ & $\square$ & 0.814 \\
\hline EINN5: Cooperated and linked with sustainable suppliers & $\square$ & $\square$ & $\square$ & $\square$ & $\square$ & 0.853 \\
\hline EINN6: Used processes and technologies focused on energy efficiency & $\square$ & $\square$ & $\square$ & $\square$ & $\square$ & 0.855 \\
\hline $\begin{array}{l}\text { EINN7: Exchanged ideas for the design of green products with } \\
\text { stakeholders (employees, customers, and suppliers) }\end{array}$ & $\square$ & $\square$ & $\square$ & $\square$ & $\square$ & 0.829 \\
\hline Corporate performance: In the last 3 years your company has achieved: & 1 & 2 & 3 & 4 & 5 & {$[16,78,79,109,110]$} \\
\hline CPERF1: Increased profits (financial profits) & $\square$ & $\square$ & $\square$ & $\square$ & $\square$ & 0.718 \\
\hline CPERF2: Increased sales of products and services & $\square$ & $\square$ & $\square$ & $\square$ & $\square$ & 0.752 \\
\hline CPERF3: Increased contribution margin (costs + expenses, income) & $\square$ & $\square$ & $\square$ & $\square$ & $\square$ & 0.758 \\
\hline CPERF4: Increased market share in the sector & $\square$ & $\square$ & $\square$ & $\square$ & $\square$ & 0.793 \\
\hline
\end{tabular}

\section{References}

1. Kanter, R.M. Innovation: The classic traps. Harv. Bus. Rev. 2006, 84, 72-83.

2. Geissdoerfer, M.; Vladimirova, D.; Evans, S. Sustainable business model innovation: A review. J. Clean. Prod. 2018, 198, 401-416. [CrossRef]

3. Teece, D.J. Business models, business strategy and innovation. Long Range Plan. 2010, 43, 172-194. [CrossRef]

4. Scuotto, V.; Del Giudice, M.; Bresciani, S.; Meissner, D. Knowledge-driven preferences in informal inbound open innovation modes. An explorative view on small to medium enterprises. J. Knowl. Manag. 2017, 21, 640-655. [CrossRef]

5. Zanjirchi, S.M.; Jalilian, N.; Mehrjardi, M.S. Open innovation: From technology exploitation to creation of superior performance. Asia Pac. J. Innov. Entrep. 2019, 13, 326-340. [CrossRef]

6. Chesbrough, H.W. Open Innovation: The New Imperative for Creating and Profiting from Technology; Harvard Business School Press: Brighton, MA, USA, 2006; ISBN 9781422102831. 
7. West, J.; Salter, A.; Vanhaverbeke, W.; Chesbrough, H. Open innovation: The next decade. Res. Policy 2014, 43, 805-811. [CrossRef]

8. Tucci, C.L.; Chesbrough, H.; Piller, F.; West, J. When do firms undertake open, collaborative activities? Introduction to the special section on open innovation and open business models. Ind. Corp. Chang. 2016, 25, 283-288. [CrossRef]

9. Zahra, S.A.; Nambisan, S. Entrepreneurship and strategic thinking in business ecosystems. Bus. Horiz. 2012, 55, 219-229. [CrossRef]

10. Gërguri-Rashiti, S.; Ramadani, V.; Abazi-Alili, H.; Dana, L.P.; Ratten, V. ICT, Innovation and Firm Performance: The Transition Economies Context. Thunderbird Int. Bus. Rev. 2017, 59, 93-102. [CrossRef]

11. Salisu, Y.; Abu Bakar, L.J. Technological capability, relational capability and firms' performance. Rev. Gestão 2019, 27, 79-99. [CrossRef]

12. De Mori, C.; Batalha, M.O.; Alfranca, O. A model for measuring technology capability in the agrifood industry companies. Br. Food J. 2016, 118, 1422-1461. [CrossRef]

13. Valdez-Juárez, L.E.; De Lema, D.G.P.; Maldonado-Guzmán, G. Management of knowledge, innovation and performance in SMEs. Interdiscip. J. Inf. Knowl. Manag. 2016, 11, 141-176. [CrossRef]

14. Jean, R.J. The ambiguous relationship of ICT and organizational performance: A literature review. Crit. Perspect. Int. Bus. 2007, 3, 306-321. [CrossRef]

15. Veronica, S.; Alexeis, G.P.; Valentina, C.; Elisa, G. Do stakeholder capabilities promote sustainable business innovation in small and medium-sized enterprises? Evidence from Italy. J. Bus. Res. 2019, 119, 131-141. [CrossRef]

16. Nosratabadi, S.; Mosavi, A.; Shamshirband, S.; Zavadskas, E.K.; Rakotonirainy, A.; Chau, K.W. Sustainable Business Models: A Review. Sustainability 2019, 11, 1663. [CrossRef]

17. Weerawardena, J.; Mavondo, F.T. Capabilities, innovation and competitive advantage. Ind. Mark. Manag. 2011, 40, 1220-1223. [CrossRef]

18. Leitão, J.; Pereira, D.; de Brito, S. Inbound and Outbound Practices of Open Innovation and Eco-Innovation: Contrasting Bioeconomy and Non-Bioeconomy Firms. J. Open Innov. Technol. Mark. Complex. 2020, 6, 145. [CrossRef]

19. Leitão, J.; de Brito, S.; Cubico, S. Eco-Innovation Influencers: Unveiling the Role of Lean Management Principles Adoption. Sustainability 2019, 11, 2225. [CrossRef]

20. Kneipp, J.M.; Gomes, C.M.; Bichueti, R.S.; Frizzo, K.; Perlin, A.P. Sustainable innovation practices and their relationship with the performance of industrial companies. Rev. Gestão 2019, 26, 94-111. [CrossRef]

21. Bocken, N.M.P.; Short, S.W.; Rana, P.; Evans, S. A literature and practice review to develop sustainable business model archetypes. J. Clean. Prod. 2014, 65, 42-56. [CrossRef]

22. Salim, H.K.; Padfield, R.; Hansen, S.B.; Mohamad, S.E.; Yuzir, A.; Syayuti, K.; Tham, M.H.; Papargyropoulou, E. Global trends in environmental management system and ISO14001 research. J. Clean. Prod. 2018, 170, 645-653. [CrossRef]

23. Teece, D.J. Explicating dynamic capabilities: The nature and microfoundations of (sustainable) enterprise performance. Strateg. Manag. J. 2007, 28, 1319-1350. [CrossRef]

24. Oduro, S. Examining open innovation practices in low-tech SMEs: Insights from an emerging market. J. Sci. Technol. Policy Manag. 2019, 10, 509-532. [CrossRef]

25. Eze, S.C.; Chinedu-Eze, V.C.; Bello, A.O. Determinants of dynamic process of emerging ICT adoption in SMEs-Actor network theory perspective. J. Sci. Technol. Policy Manag. 2019, 10, 2-34. [CrossRef]

26. Anderson, R.W.; Acur, N.; Corney, J. How do SMEs Use Open Innovation When Developing New Business Models? In Researching Open Innovation in SMEs; World Scientific: Singapore, 2018; pp. 179-209.

27. Wonglimpiyarat, J. Challenges of SMEs innovation and entrepreneurial financing. World J. Entrep. Manag. Sustain. Dev. 2015, 11, 295-311. [CrossRef]

28. Eggers, F. Masters of disasters? Challenges and opportunities for SMEs in times of crisis. J. Bus. Res. 2020, 116, 199-208. [CrossRef]

29. Garcia, R.; Wigger, K.; Hermann, R.R. Challenges of creating and capturing value in open eco-innovation: Evidence from the maritime industry in Denmark. J. Clean. Prod. 2019, 220, 642-654. [CrossRef]

30. Cheng, C.C.J.; Shiu, E.C. Leveraging open innovation strategies for fueling eco-innovation performance in dynamic environments. Sustain. Account. Manag. Policy J. 2020, 11, 1245-1270. [CrossRef]

31. Salim, N.; Ab Rahman, M.N.; Abd Wahab, D. A systematic literature review of internal capabilities for enhancing eco-innovation performance of manufacturing firms. J. Clean. Prod. 2019, 209, 1445-1460. [CrossRef]

32. Badir, Y.F.; Frank, B.; Bogers, M. Employee-level open innovation in emerging markets: Linking internal, external, and managerial resources. J. Acad. Mark. Sci. 2020, 48, 891-913. [CrossRef]

33. Agostini, L.; Nosella, A. Inter-organizational relationships involving SMEs: A bibliographic investigation into the state of the art. Long Range Plann. 2018, 52, 1-31. [CrossRef]

34. Miao, C.; Rutherford, M.W.; Pollack, J.M. An exploratory meta-analysis of the nomological network of bootstrapping in SMEs J. Bus. Ventur. Insights 2017, 8, 1-8. [CrossRef]

35. Abubakar, Y.A.; Hand, C.; Smallbone, D.; Saridakis, G. What specific modes of internationalization influence SME innovation in Sub-Saharan least developed countries (LDCs)? Technovation 2019, 79, 56-70. [CrossRef]

36. Wang, Y.; Lo, H.-P.; Zhang, Q.; Xue, Y. How technological capability influences business performance: An integrated framework based on the contingency approach. J. Technol. Manag. China 2006, 1, 27-52. [CrossRef] 
37. Ulas, D. Digital Transformation Process and SMEs. In Proceedings of the Procedia Computer Science; Elsevier BV: Amsterdam, The Netherlands, 2019; Volume 158, pp. 662-671.

38. Hassan, M.U.; Iqbal, Z.; Malik, M.; Ahmad, M.I. Exploring the role of technological developments and open innovation in the survival of SMEs: An empirical study of Pakistan. Int. J. Bus. Forecast. Mark. Intell. 2018, 4, 64-85. [CrossRef]

39. Weber, D.M. The Impact of Information and Communication Technology on Intermediation, Outreach, and Decision Rights in the Microfinance Industry. Ph.D. Thesis, Arizona State University, Tempe, AZ, USA, 2012; p. 207.

40. Civelek, F.; Kulkarni, R.; Fritz, K.-P.; Meyer, T.; Troulos, C.; Guenther, T.; Zimmermann, A. Open-Eco-Innovation for SMEs with Pan-European Key Enabling Technology Centres. Clean Technol. 2020, 2, 422-439. [CrossRef]

41. Wehn, U.; Montalvo, C. Knowledge transfer dynamics and innovation: Behaviour, interactions and aggregated outcomes. J. Clean Prod. 2018, 171, S56-S68. [CrossRef]

42. Yu, Y.; Dong, X.Y.; Shen, K.N.; Khalifa, M.; Hao, J.X. Strategies, technologies, and organizational learning for developing organizational innovativeness in emerging economies. J. Bus. Res. 2013, 66, 2507-2514. [CrossRef]

43. Sáez-Martínez, F.J.; Díaz-García, C.; Gonzalez-Moreno, A. Firm technological trajectory as a driver of eco-innovation in young small and medium-sized enterprises. J. Clean. Prod. 2016, 138, 28-37. [CrossRef]

44. Kuo, T.C.; Smith, S. A systematic review of technologies involving eco-innovation for enterprises moving towards sustainability. J. Clean. Prod. 2018, 192, 207-220. [CrossRef]

45. Halme, M.; Korpela, M. Responsible Innovation toward Sustainable Development in Small and Medium-Sized Enterprises: A Resource Perspective. Bus. Strateg. Environ. 2014, 23, 547-566. [CrossRef]

46. Bagheri, M.; Mitchelmore, S.; Bamiatzi, V.; Nikolopoulos, K. Internationalization Orientation in SMEs: The Mediating Role of Technological Innovation. J. Int. Manag. 2019, 25, 121-139. [CrossRef]

47. Chege, S.M.; Wang, D.; Suntu, S.L. Information Technology for Development Impact of Information Technology Innovation on Firm Performance in Kenya Impact of Information Technology Innovation on Firm Performance in Kenya; Taylor Francis Group: Abingdon, UK, 2020; Volume 26, pp. 316-345. [CrossRef]

48. Azam, M.S. Diffusion of ICT and SME performance. Adv. Bus. Mark. Purch. 2015, 23A, 7-290. [CrossRef]

49. Kumar, R.; Singh, R.K.; Dwivedi, Y.K. Application of industry 4.0 technologies in SMEs for ethical and sustainable operations: Analysis of challenges. J. Clean. Prod. 2020, 275, 124063. [CrossRef]

50. Fernández-Portillo, A.; Almodóvar-González, M.; Hernández-Mogollón, R. Impact of ICT development on economic growth. A study of OECD European union countries. Technol. Soc. 2020, 63, 101420. [CrossRef]

51. Cenamor, J.; Parida, V.; Wincent, J. How entrepreneurial SMEs compete through digital platforms: The roles of digital platform capability, network capability and ambidexterity. J. Bus. Res. 2019, 100, 196-206. [CrossRef]

52. Keinz, P.; Marhold, K. Technological competence leveraging projects via intermediaries: Viable means to outbound open innovation and mediated capability building? Int. J. Proj. Manag. 2020. [CrossRef]

53. Singh, S.K.; Gupta, S.; Busso, D.; Kamboj, S. Top management knowledge value, knowledge sharing practices, open innovation and organizational performance. J. Bus. Res. 2019. [CrossRef]

54. Crema, M.; Verbano, C.; Venturini, K. Linking strategy with open innovation and performance in SMEs. Meas. Bus. Excell. 2014, 18, 14-27. [CrossRef]

55. Zhang, J.A.; Walton, S. Eco-innovation and business performance: The moderating effects of environmental orientation and resource commitment in green-oriented SMEs. $R$ D Manag. 2017, 47, E26-E39. [CrossRef]

56. Costa, J.; Matias, J.C.O. Open Innovation 4.0 as an Enhancer of Sustainable Innovation Ecosystems. Sustainability 2020, $12,8112$. [CrossRef]

57. Marin, G.; Marzucchi, A.; Zoboli, R. SMEs and barriers to Eco-innovation in the EU: Exploring different firm profiles. J. Evol. Econ. 2015, 25, 671-705. [CrossRef]

58. Barbieri, R.; Santos, D.F.L. Sustainable business models and eco-innovation: A life cycle assessment. J. Clean. Prod. 2020, 266, 121954. [CrossRef]

59. Economic Commission for Latin America and the Caribbean (CEPAL). Sectors and Companies Facing COVID-19: Emergency and Reactivation; CEPAL: Santiago, Chile, 2020.

60. Global Entrepreneurship Monitor (GEM). Global Entrepreneurship Monitor 2019/2020 Global Report; GEM: London, UK, 2020; Volume 8.

61. World Bank. World Bank World Development Indicators Database; World Bank: Washington, DC, USA, 2007.

62. Porto-Gomez, I.; Zabala-Iturriagagoitia, J.M.; Leydesdorff, L. Innovation systems in México: A matter of missing synergies. Technol. Forecast. Soc. Chang. 2019, 148, 119721. [CrossRef]

63. López Mejia, M.; Gómez Martínez, A.; Sánchez Meléndez, M.D. Gestión De Las Pyme En México. Ante Los Nuevos Escenarios de Negocios y La Teoría de la Agencia. Estud. Adm. 2020, 27, 69-91. [CrossRef]

64. Instituto Nacional de Geografía, Estadística e Informática (INEGI). Censos Económicos 2019; INEGI: Mexico City, Mexico, 2019.

65. Bianchi, C.; Carneiro, J.; Wickramasekera, R. Internationalisation commitment of emerging market firms: A comparative study of Chile and Brazil. J. Small Bus. Enterp. Dev. 2018, 25, 201-221. [CrossRef]

66. De Oliveira, R.T.; Verreynne, M.L.; Figueira, S.; Indulska, M.; Steen, J. How do institutional innovation systems affect open innovation? J. Small Bus. Manag. 2020, 1-45. [CrossRef] 
67. Gorrell, G.; Ford, N.; Madden, A.; Holdridge, P.; Eaglestone, B. Countering method bias in questionnaire-based user studies. J. Doc. 2011, 67, 507-524. [CrossRef]

68. Podsakoff, P.M.; MacKenzie, S.B.; Lee, J.; Podsakoff, N.P. Common Method Bias in Behavioral Research: A Critical Review of the Literature and recommended remedies. J. Appl. Psychol. 2003, 88, 879-903. [CrossRef]

69. Sarstedt, M.; Hair, J.F.; Cheah, J.H.; Becker, J.M.; Ringle, C.M. How to specify, estimate, and validate higher-order constructs in PLS-SEM. Australas. Mark. J. 2019, 27, 197-211. [CrossRef]

70. Hair, J.F.; Risher, J.J.; Sarstedt, M.; Ringle, C.M. When to use and how to report the results of PLS-SEM. Eur. Bus. Rev. 2019, 31, 2-24. [CrossRef]

71. Henseler, J.; Hubona, G.; Ray, P.A. Using PLS path modeling in new technology research: Updated guidelines. Ind. Manag. Data Syst. 2016, 116, 2-20. [CrossRef]

72. Weijters, B.; Cabooter, E.; Schillewaert, N. The effect of rating scale format on response styles: The number of response categories and response category labels. Int. J. Res. Mark. 2010, 27, 236-247. [CrossRef]

73. Sá, E.S.; de Pinho, J.C.M.R. Effect of entrepreneurial framework conditions on R\&D transfer to new and growing firms: The case of European Union innovation-driven countries. Technol. Forecast. Soc. Chang. 2019, 141, 47-58. [CrossRef]

74. Duncan, N.B. Capturing Flexibility of Information Technology Infrastructure: A Study of Resource Characteristics and Their Measure. J. Manag. Inf. Syst. 1995, 12, 37-57. [CrossRef]

75. OECD. The Measurement of Scientific and Technological Activities. Manual de Oslo; European Commission: Madrid, Spain, 2006.

76. Bocken, N.M.P.; Farracho, M.; Bosworth, R.; Kemp, R. The front-end of eco-innovation for eco-innovative small and medium sized companies. J. Eng. Technol. Manag. 2014, 31, 43-57. [CrossRef]

77. Cheng, C.C.; Shiu, E.C. Validation of a proposed instrument for measuring eco-innovation: An implementation perspective. Technovation 2012, 32, 329-344. [CrossRef]

78. Loorbach, D.; Wijsman, K. Business transition management: Exploring a new role for business in sustainability transitions. J. Clean. Prod. 2013, 45, 20-28. [CrossRef]

79. Aguilera-Caracuel, J.; Ortiz-de-Mandojana, N. Green Innovation and Financial Performance. Organ. Environ. 2013, 26, 365-385. [CrossRef]

80. Henseler, J.; Ringle, C.M.; Sarstedt, M. Testing measurement invariance of composites using partial least squares. Int. Mark. Rev. 2016, 33, 405-431. [CrossRef]

81. Henseler, J.; Dijkstra, T.K.; Sarstedt, M.; Ringle, C.M.; Diamantopoulos, A.; Straub, D.W.; Ketchen, D.J.; Hair, J.F.; Hult, G.T.M.; Calantone, R.J. Common Beliefs and Reality about PLS. Organ. Res. Methods 2014, 17, 182-209. [CrossRef]

82. Fornell, C.; Larcker, D.F. Evaluating Structural Equation Models with Unobservable Variables and Measurement Error. J. Mark. Res. (JMR) 1981, 18, 39-50. [CrossRef]

83. Chin, W.W. The partial least squares approach to structural equation modeling. In Methodology for Business and Management. Modern Methods for Business Research; Marcoulides, G.A., Ed.; Lawrence Erlbaum Associates Publishers: Mahwah, NJ, USA, 1998; pp. 295-336.

84. Falk, R.; Miller, N. A Primer for Soft Modeling; University of Akron Press: Akron, OH, USA, 1992.

85. Cohen, J. Set Correlation and Contingency Tables. Appl. Psychol. Meas. 1988, 12, 425-434. [CrossRef]

86. Hu, L.; Bentler, P.M. Cutoff criteria for fit indexes in covariance structure analysis: Conventional criteria versus new alternatives. Struct. Equ. Model. A Multidiscip. J. 1999, 6, 1-55. [CrossRef]

87. Chin, W.W.; Dibbern, J. Handbook of Partial Least Squares; Springer: Berlin/Heidelberg, Germany, 2010; ISBN 978-3-540-32825-4.

88. Nitzl, C.; Roldan, J.L.; Cepeda, G. Mediation analysis in partial least squares path modelling, Helping researchers discuss more sophisticated models. Ind. Manag. Data Syst. 2016, 116, 1849-1864. [CrossRef]

89. Hair, J.F., Jr.; Sarstedt, M.; Hopkins, L.; Kuppelwieser, V.G. Partial least squares structural equation modeling (PLS-SEM). Eur. Bus. Rev. 2014, 26, 106-121. [CrossRef]

90. Carrión, G.C.; Nitzl, C.; Roldán, J.L. Mediation Analyses in Partial Least Squares Structural Equation Modeling: Guidelines and Empirical Examples. In Partial Least Squares Path Modeling; Springer International Publishing: Cham, Switerland, 2017; pp. 173-195.

91. Hair, J.F., Jr.; Sarstedt, M.; Ringle, C.M.; Gudergan, S.P. Advanced Issues in Partial Least Squares Structural Equation Modeling; SAGE: Thousand Oaks, CA, USA, 2017; ISBN 1483377385, 9781483377384.

92. International Organization for Standardization (ISO). ISO 14001:2015: Environmental Management Systems: A Practical Guide for SMEs; ISO: Geneva, Switzerland, 2017.

93. Ullah, B.; Wei, Z.; Xie, F. ISO certification, financial constraints, and firm performance in Latin American and Caribbean countries. Glob. Financ. J. 2014, 25, 203-228. [CrossRef]

94. Piyathanavong, V.; Garza-Reyes, J.A.; Kumar, V.; Maldonado-Guzmán, G.; Mangla, S.K. The adoption of operational environmental sustainability approaches in the Thai manufacturing sector. J. Clean. Prod. 2019, 220, 507-528. [CrossRef]

95. Grazzi, M.; Sasso, S.; Kemp, R. A Conceptual Framework to Measure Green Innovation in Latin America and the Caribbean; InterAmerican Development Ban: Washington, DC, USA, 2019. [CrossRef]

96. González-Moreno, Á.; Triguero, Á.; Sáez-Martínez, F.J. Many or trusted partners for eco-innovation? The influence of breadth and depth of firms' knowledge network in the food sector. Technol. Forecast. Soc. Chang. 2019, 147, 51-62. [CrossRef] 
97. Cainelli, G.; De Marchi, V.; Grandinetti, R. Does the development of environmental innovation require different resources? Evidence from Spanish manufacturing firms. J. Clean. Prod. 2015, 94, 211-220. [CrossRef]

98. Usman, M.; Vanhaverbeke, W. How start-ups successfully organize and manage open innovation with large companies. Eur. J. Innov. Manag. 2017, 20, 171-186. [CrossRef]

99. Zimmermann, H.-D.; Pucihar, A. Open Innovation, Open Data and New Business Models. Sci. Organ. 2015, 449-458. [CrossRef]

100. Yun, J.J.; Zhao, X.; Park, K. Sustainability Condition of Open Innovation: Dynamic Growth of Alibaba from SME to Large Enterprise. Sustainability 2020, 12, 4379. [CrossRef]

101. Audretsch, D.B.; Belitski, M. The missing pillar: The creativity theory of knowledge spillover entrepreneurship. Small Bus. Econ. 2013, 41, 819-836. [CrossRef]

102. Jugend, D.; Fiorini, P.D.C.; Armellini, F.; Ferrari, A.G. Public support for innovation: A systematic review of the literature and implications for open innovation. Technol. Forecast. Soc. Chang. 2020, 156, 119985. [CrossRef]

103. Jones-Evans, D.; Gkikas, A.; Rhisiart, M.; MacKenzie, N.G. Measuring open innovation in SMEs. In Researching Open Innovation in SMEs; World Scientific Publishing Co. Pte. Ltd.: Singapore, 2018; pp. 399-427. ISBN 9789813230972.

104. Van de Vrande, V.; de Jong, J.P.J.; Vanhaverbeke, W.; de Rochemont, M. Open innovation in SMEs: Trends, motives and management challenges. Technovation 2009, 29, 423-437. [CrossRef]

105. Pigosso, D.C.A.; Schmiegelow, A.; Andersen, M.M. Measuring the Readiness of SMEs for Eco-Innovation and Industrial Symbiosis: Development of a Screening Tool. Sustainabiity 2018, 10, 2861. [CrossRef]

106. Klewitz, J.; Zeyen, A.; Hansen, E.G. Intermediaries driving eco-innovation in SMEs: A qualitative investigation. Eur. J. Innov. Manag. 2012, 15, 442-467. [CrossRef]

107. De Jesus Pacheco, D.A.; Carla, S.; Jung, C.F.; Ribeiro, J.L.D.; Navas, H.V.G.; Cruz-Machado, V.A. Eco-innovation determinants in manufacturing SMEs: Systematic review and research directions. J. Clean. Prod. 2017, 142, 2277-2287. [CrossRef]

108. García-Granero, E.M.; Piedra-Muñoz, L.; Galdeano-Gómez, E. Measuring eco-innovation dimensions: The role of environmental corporate culture and commercial orientation. Res. Policy 2020, 49, 104028. [CrossRef]

109. Quinn, R.E.; Rohrbaugh, J. A Spatial Model of Effectiveness Criteria: Towards a Competing Values Approach to Organizational Analysis A Spatial Model of Effectiveness Criteria: Towards a Competing Values Approach to Organizational Analysis. Manag. Sci. 2011, 29, 363-377. [CrossRef]

110. Neely, A.D.; Adams, M.K.C. The Performance Prism: The Scorecard for Measuring and Managing Business Success Classification of Noisy Data: A Data Mining Challenge View Project; Pearson Education: London, UK, 2002; ISBN 0273653342. 